Published in final edited form as:

Curr Gastroenterol Rep. 2016 July ; 18(7): 33. doi:10.1007/s11894-016-0509-x.

\title{
Eradication of Helicobacter pylori infection
}

\author{
Elizabeth A. Marcus ${ }^{1,4,}{ }^{*}$, George Sachs ${ }^{2,3,4}$, and David R. Scott ${ }^{2,4}$ \\ ${ }^{1}$ Department of Pediatrics, DGSOM at UCLA \\ 2Department of Physiology, DGSOM at UCLA \\ ${ }^{3}$ Department of Medicine, DGSOM at UCLA \\ ${ }^{4}$ VA GLAHS, Los Angeles, CA
}

\begin{abstract}
Helicobacter pylori infects about 50\% of the world's population, causing at a minimum chronic gastritis. A subset of infected patients will ultimately develop gastric or duodenal ulcer disease, gastric adenocarcinoma, or MALT (mucosa-associated lymphoid tissue) lymphoma. Eradication of H. pylori requires complex regimens that include acid suppression and multiple antibiotics. The efficacy of treatment using what were once considered standard regimens have declined in recent years, mainly due to widespread development of antibiotic resistance. Addition of bismuth to standard triple therapy regimens, use of alternate antibiotics, or development of alternative regimens using known therapies in novel combinations, have improved treatment efficacy in specific populations, but overall success of eradication remains less than ideal. Novel regimens under investigation either in vivo or in vitro, involving increased acid suppression ideally with fewer antibiotics or development of non-antibiotic treatment targets show promise for future therapy.
\end{abstract}

\section{Keywords}

Helicobacter pylori; gastric acid; antibiotic resistance; eradication

\section{Introduction}

Helicobacter pylori, a gram negative bacteria that infects the normal acid secreting human stomach, was first connected to the development of ulcer disease in 1984 [1]. The bacteria infects about $50 \%$ of the world's population, leading to gastritis in $100 \%$ of those infected, and a fraction of those individuals will ultimately develop gastric or duodenal ulcer disease, gastric adenocarcinoma, or MALT (mucosa-associated lymphoid tissue) lymphoma [2-6] $H$. pylori was designated as a class one or definite carcinogen by the World Health Organization on the basis of the established connection with gastric cancer [7,8]. The worldwide burden of gastric cancer is high. Gastric cancer is the $4^{\text {th }}$ most common cancer and the $2^{\text {nd }}$ most

\footnotetext{
*Corresponding author Elizabeth A. Marcus, MD, emarcus@mednet.ucla.edu, 310-478-3711 x42045.

George Sachs, DSc, MD, gsachs@ucla.edu, 310-268-3923

David R. Scott, PhD, dscott@ucla.edu, 310-478-3711 x42046

Address for all authors: VA GLAHS, 11301 Wilshire Blvd., Bldg 113 Rm 324, Los Angeles, CA 90073, Fax 310-312-9478
} 
common cause of cancer death [9]. Eradication of $H$. pylori infection leads to improvement or resolution of associated pathology, underscoring the importance of effective therapy. Successful treatment of $H$. pylori leads to ulcer healing rates of $>90 \%$ and is effective in preventing recurrence of bleeding [10-12]. Low-grade MALT lymphoma, in the absence of genetic translocations, can be treated by eradication of $H$. pylori [13-15]. Eradication of $H$. pylori is proven to be beneficial for prevention of gastric cancer [16] and leads to eventual regression of acute and chronic inflammation [17]. Success rates of standard therapy regimens, typically including acid suppression and multiple antibiotics, has fallen below the acceptable level of $80 \%$ in many parts of the world [18]. The reason for the decline in treatment success appears to be multifactorial, involving issues such as expanding antibiotic resistance, patient compliance, and host and bacterial factors that alter the efficacy of treatment [19]. Antibiotic resistance is generally believed to be the major contributor to treatment failure, underscoring the importance of understanding why current regimens fail and identifying new treatment regimens.

\section{Scientific basis for standard therapy}

H. pylori colonizes an acidic niche in the human stomach. It was originally believed that, even though the gastric lumen has a median $\mathrm{pH}$ near 1.4 in normal acid secreting humans [20], the actual site of infection was closer to neutral $\mathrm{pH}$ due to a $\mathrm{pH}$ gradient through the mucus layer [21]. These studies were done with glass-tipped microelectrodes, and may have been hindered by technique due to difficulty in diffusion of protons through the electrodes. Several studies in the interim have provided evidence for a more acidic environment at the site of infection. Later work using mircoelectrodes in mice have suggested that the presence of $H$. pylori removes any potential barriers to proton diffusion [22]. Fluorescent dye studies completed in externalized stomachs of anesthetized mice also suggested an acidic $\mathrm{pH}$ at the gastric surface, regardless of the presence of a mucus layer [23]. The gastric surface $\mathrm{pH}$ is a combination of regulation of acid and alkali secretion to a specific set point rather than a result of trapping of buffers or protons under the mucus layer [23]. Transcriptome studies done in vitro at acidic and neutral $\mathrm{pH}$ and in bacteria collected from infected gerbils demonstrated that genes regulated by acidic $\mathrm{pH}$ in vitro show similar changes in expression in the gerbil stomach, again suggesting acidic $\mathrm{pH}$ at the site of infection [24]. $\mathrm{H}$. pylori typically infects the gastric antrum but the infection predominates in the gastric body with acid suppressive therapy [25-28], providing additional evidence that the bacteria are adapted to live in a very specific environment with regard to local $\mathrm{pH}$.

In apparent conflict with the need for $H$. pylori to inhabit an acidic niche, the bacteria are bioenergetically neutralophiles, meaning they are able to survive between $\mathrm{pH}$ 4-8 and grow between $\mathrm{pH} 6-8$. The bioenergetic profile has been confirmed using studies measuring membrane potential [29]. The bacteria have adapted to survive in their very specific niche through a mechanism termed acid acclimation, or the ability to maintain periplasmic $\mathrm{pH}$ near neutral in an acidic environment [30]. This is distinct from the acid resistance mechanisms seen in other bacteria that merely have to survive passage through the stomach and designed to moderately elevate cytoplasmic $\mathrm{pH}$ [31]. Acid acclimation in $H$. pylori is centered on a neutral $\mathrm{pH}$ optimum cytoplasmic urease enzyme, which hydrolyzes urea into carbonic acid and ammonia, and an inner membrane localized, proton gated urea channel, 
UreI [30,32,33]. A periplasmic-localized a-carbonic anhydrase enzyme contributes to periplasmic buffering by catalyzing the conversion of carbon dioxide produced by urease into bicarbonate [30]. The bacteria are able to sense environmental $\mathrm{pH}$ via the use of twocomponent signaling systems, which are able to stimulate protein trafficking, facilitating periplasmic alkalization, and increase transcription of acid acclimation genes [34].

Acid acclimation and $H$. pylori bioenergetics are critical to successful treatment protocols. Available regimens are classically based on acid suppression and multiple antibiotics. The bacteria are uniquely adapted to survive in the acidic environment of the stomach, but based on their status as neutralophiles, a smaller fraction of the bacteria will actually be dividing or growing in acid as compared to more neutral $\mathrm{pH}$. This is demonstrated in transcriptome studies, where genes involved in cell division and cell wall synthesis are up-regulated at neutral $\mathrm{pH}$ [35]. Most antibiotics used to treat $H$. pylori are dependent on bacterial growth and will work on bacteria that are actively dividing, which will occur more readily with adequate acid suppression [35]. H. pylori that are not dividing at the time of antibiotic administration will not be killed by the antibiotics, leaving a small population of viable bacteria that can restore colonization of the stomach once the antibiotics are stopped. This is considered a form of pheonotypic resistance, where treatment can fail despite appropriate antibiotic coverage [36, 37]. Medications currently available for acid blockade, at recommended doses, will not consistently achieve the sustained $\mathrm{pH}$ change required to mimic the bactericidal effect seen in in vitro studies [35,38].

\section{Standard triple and bismuth-containing quadruple therapy}

Standard first line treatment for $H$. pylori infection has classically been triple therapy with BID PPI, clarithromycin, and either metronidazole or amoxicillin. Clarithromycin is bacteriostatic and inhibits protein synthesis by binding to the $50 \mathrm{~S}$ ribosomal subunit. Metronidazole is bactericidal and works via activation within the bacteria, leading to production of toxic metabolites. Amoxicillin is bactericidal and inhibits synthesis of bacterial cell walls. Efficacy is equivalent when using either amoxicillin or metronidazole [39]. Use of high dose BID PPI will increase cure rates with standard therapy regimens by 6-10\% [40]. Treatment duration is important as well, as a fourteen day dosing schedule increased efficacy of eradication by 5-6\% when compared to a seven day regimen, without causing a significant difference in side effect profile [41-43]. Standard triple therapy was initially acceptably efficacious, with treatment success ranging from $>80 \%$ to $>90 \%$ in the early 1990s [44, 45]. Success of this regimen has declined globally over time, dropping to unacceptable levels in many regions [46, 19]. The main identified reason for treatment failure with standard triple therapy is resistance to clarithromycin, with compliance, bacterial load, and strain differences also identified as potential contributing factors [47]. Clarithromycin resistance is mediated either by point mutations that prevent antibiotic binding to the ribosome or via development of antibiotic efflux channels [48, 49]. When deciding to use standard triple therapy, it is important to review a patient's prior antibiotic use since past exposure to any of the macrolide antibiotics may predict clarithromycin resistance [50]. Current guidelines suggest that standard triple therapy should not be used if regional levels of clarithromycin resistance are >15-20\% [47]. Metronidazole resistance, mediated by mutations leading to inactivation of the bacterial enzymes needed to activate the 
antibiotic, is also fairly prevalent worldwide [51, 52]. Like clarithromycin, prior exposure to metronidazole is an important factor in treatment success [50]. Two important differences exist when comparing metronidazole resistance to clarithromycin resistance. Metronidazole resistance has remained more stable worldwide while clarithromycin resistance has increased [53]. Metronidazole resistance can also be overcome by increasing the antibiotic dose $[54,55]$. Amoxicillin resistance, mediated by a variety of different mechanisms including mutations in penicillin binding proteins, decreased permeability for the antibiotic, or development of efflux pumps, is extremely rare in $H$. pylori $[47,56]$.

In the case of failed standard triple therapy, or as first line therapy in regions of high clarithromycin resistance, bismuth-containing quadruple regimens can be considered [47]. These regimens consist of BID PPI, bismuth, and two antibiotics [47], ideally for fourteen days, and have overall improved efficacy compared with triple therapy in regions with higher levels of clarithromycin or metronidazole resistance [57]. Several recent studies have confirmed efficacy of adding bismuth to clarithromycin or levofloxacin-containing regimens, even in the setting of either high levels of resistance or known resistance based on susceptibility testing. Cure rates across these studies were either $>90 \%$ for fourteen day regimens or demonstrated improvement from region-based expected eradication levels of $30-40 \%$ up to $70-85 \%\left[58^{-} 61,55\right]$. Resistance of $H$. pylori to bismuth has not been reported [62-64]. The mechanism of action of bismuth on $H$. pylori is not definitively known. Bismuth preparations, on rare occasions, have been noted to have some independent bactericidal action against $H$. pylori [65-67]. Bismuth has mainly a local effect on $H$. pylori, as absorption is not required for efficacy [68]. Older in vitro studies suggest that bismuth may work against $H$. pylori via deposition both on the surface of the bacteria and in the region between the cell wall and the cytoplasmic membrane, disrupting critical bacterial functions $[69,70]$. More recent in vitro work suggests that bismuth impedes proton entry into the bacteria, allowing for up-regulation of growth-dependent genes and increased efficacy of growth-dependent antibiotics [71]. The downsides to bismuth-containing quadruple therapy include increased complexity of the regimens and increased side-effect potential, which may interfere with compliance. Having a non-antibiotic component as part of a widely-used regimen has the long-term benefit of durability of response, without the concern for development of resistance over time.

\section{Alternative antibiotics}

Rising resistance rates and antibiotic availability in different regions may necessitate the use of different antibiotics beyond the standard therapy protocols. The most common antibiotic used in second line or salvage therapies is levofloxacin. Levofloxacin works by inhibiting bacterial topoisomerase II [72]. In most cases of failed $1^{\text {st }}$ line therapy, it is assumed that antibiotic resistance may have played a role, and antibiotics should be altered [37]. Triple therapy with levofloxacin replacing clarithromycin, given that amoxicillin resistance is extremely rare, is a recommended $2^{\text {nd }}$ line regimen [47]. Levofloxacin can also be substituted for clarithromycin in a variety of alternative regimens based on local resistance patterns. Levofloxacin and other fluoroquinolones are widely used for a variety of bacterial infections and levofloxacin should not be considered for treatment of $H$. pylori in patients with a history of chronic infections treated with this class of antibiotics [47]. Due to its 
widespread and growing use worldwide, the incidence of levofloxacin-resistant $H$. pylori is growing rapidly [37]. Resistance is typically caused by point mutations in the H. pylori DNA gyrase [73, 74]. 14-day triple therapy with levofloxacin will not reach the target of $90 \%$ success if the local resistance rate is over $12 \%$, and addition of bismuth requires a local resistance rate of under $25 \%$ [75, 60]. Overall, levofloxacin can be considered as a reasonable $2^{\text {nd }}$ line regimen if local clarithromycin resistance exceeds $15-20 \%$ and levofloxacin resistance is less than $10 \%$, or as part of an empiric salvage regimen in areas of low fluoroquinolone resistance $[47,76]$.

Tetracycline is bactericidal and works by inhibiting protein synthesis. Tetracycline resistance, mediated either by efflux proteins or ribosomal protection proteins [77], is less prevalent worldwide than resistance to clarithromycin, metronidazole, or levofloxacin. In patients in Taiwan receiving a $2^{\text {nd }}$ course of treatment for a prior failure, addition of tetracycline to PPI, bismuth, and amoxicillin was more effective than addition of metronidazole [78]. Use of tetracycline has become more prominent since the introduction of Pylera ${ }^{\circledR}$, a combined pill containing bismuth, tetracycline, and metronidazole that can be taken four times daily in combination with a twice daily PPI. The benefit of this combined pill formulation is the likelihood of improved patient compliance. Use of Pylera ${ }^{\circledR}$ resulted in eradication rates of $80-93 \%$ in a series of studies conducted in populations who were either treatment naïve or had failed 1 treatment course [79-82]. A more recent study looked at effectiveness of this regimen in patients with known resistance to metronidazole, clarithromycin, and levofloxacin or who had failed multiple prior treatment courses, and found eradication rates of $83 \%$ (intention to treat) and $87 \%$ (per-protocol) [83]. These numbers are encouraging especially in the setting of known metronidazole resistance and in a difficult to treat population. Tetracycline should be considered as a part of $2^{\text {nd }}$ line or salvage regimens, typically as a part of bismuth-containing quadruple therapy regimens, especially in areas where antibiotic resistance is of high concern.

Rifabutin is a bactericidal antibiotic that works by blocking bacterial RNA polymerase. Resistance of $H$. pylori to rifabutin is very low, about $1 \%$ overall [37], typically mediated by genomic point mutations $[84,85]$. The most commonly used rifabutin-containing regimen is in combination with a PPI and amoxicillin for 14 days, with greater efficacy (over 90\%) seen when using high doses of both the PPI and amoxicillin [86, 87]. The mean success rate of regimens containing rifabutin is $73 \%$ according to a comprehensive review completed in 2012 [88]. Rifabutin should only be used as a salvage therapy due to the potential for creating resistance to mycobacteria and the risk of side effects such as myelotoxicity [88].

\section{Alternative regimens}

Several alternative treatment regimens designed to overcome the problems faced with standard protocols have been developed and extensively tested. Sequential therapy is a 10 day regimen which begins with five days of BID PPI and amoxicillin (or levofloxacin if penicillin-allergic), with discontinuation of amoxicillin and initiation of clarithromycin and metronidazole for treatment days 6-10 [47, 89, 90]. This regimen can be extended to 14 days, with reported superiority over standard triple therapy for 14 days in a recent multicenter study completed in Taiwan [91]. The rationale for this regimen is that the amoxicillin 
is used to help overcome clarithromycin resistance. By disrupting bacterial cell walls, amoxicillin interferes with the activation of clarithromycin efflux channels in resistant organisms [89, 49]. Sequential therapy is considered first line treatment in regions of high clarithromycin resistance where bismuth is not readily available [47]. In one analysis, sequential therapy was shown to be effective $75 \%$ of the time in clarithromycin-resistant strains [92]. A recent meta-analysis demonstrated that 14 day sequential therapy was a more effective first-line regimen than 14 day triple therapy [93]. The downsides to sequential therapy include challenges with patient compliance with a complex regimen and the potential to either foster resistance to multiple antibiotics or limit salvage options in the event of treatment failure $[94,76]$.

Concomitant therapy, or non-bismuth quadruple therapy, includes a PPI and 3 antibiotics, typically clarithromycin, amoxicillin, and metronidazole, ideally for 14 days. This regimen is superior to standard triple therapy as demonstrated in a recent randomized controlled trial and multiple meta-analyses [95-97]. The appeal of this regimen as compared to sequential therapy is that there is no need to change antibiotics half way through the treatment course, which is easier for patients and should boost compliance [37]. This regimen shows reasonable success in areas of high clarithromycin or metronidazole resistance, but efficacy drops when the prevalence of strains resistant to both antibiotics is greater than $15 \%$, such as Latin America, Turkey, or Korea [98].

Hybrid therapy is a combination of sequential and concomitant therapy, starting with seven days of PPI and amoxicillin, followed by addition of clarithromycin and metronidazole (4drug regimen) for the final seven days [99]. Reverse hybrid therapy involves all four drugs for the first seven days, followed by amoxicillin and PPI for the final seven days [100]. Since medications are added during treatment rather than changed, this regimen should be simpler than sequential therapy. There is less overall antibiotic exposure than with concomitant therapy, potentially making this regimen more attractive in regions where it is effective. Similar to concomitant therapy, effectiveness will be decreased in regions with high prevalence of strains with combined metronidazole and clarithromycin resistance [98]. Success rates, as expected, are region-dependent [37]. A meta-analysis completed in early 2015 showed overall similar efficacy when comparing hybrid, concomitant, and sequential therapies [101]. A meta-analysis completed later in 2015 included eight studies and 2516 enrolled subjects and again showed hybrid therapy was similar to sequential therapy and to concomitant therapy in terms of success rate and concluded that hybrid therapy was overall effective and well-tolerated [100]. Based on the available literature, the overall decision to choose an alternative regimen should be based on local resistance patterns, prior antibiotic exposures (relating to H. pylori treatment or other infections), and expected patient compliance.

\section{The future of therapy}

The two most significant barriers to effective treatment for $H$. pylori infection are antibiotic resistance and patient compliance. With this in mind, the future of treatment needs to be focused on either simpler regimens, use of antibiotics with less chance of development of resistance, or development of non-antibiotic regimens targeting the ability of the bacteria to 
survive in the stomach. Both primary and secondary resistance of $H$. pylori to amoxicillin are very rare [102¹04], making this antibiotic a viable candidate for study of dual therapy regimens with PPIs. Dual therapy with PPI and amoxicillin has been studied in different formats for over 20 years, but consistency in results has not been established, and fine tuning is likely required to establish this regimen as a standard treatment protocol. A meta-analysis completed in 1994 suggested a $>80 \%$ eradication rate with omeprazole 20mg BID and amoxicillin $>2 \mathrm{~g}$ total daily and hinted at the importance of acid suppression in these regimens. Success rates of 30-50\% were seen with similar dual regimens in 1995 and 1998 [105, 106], but most significantly, the 1998 study highlighted the importance of profound acid suppression. The only significant factors in successful eradication with PPI-amoxicillin dual therapy were percent time $>\mathrm{pH} 4$ and continuous time $>\mathrm{pH} 6$ [106]. More recently, the recognition of P450 CYP 2C19 polymorphisms that affect the metabolism of PPIs has presented a possible mechanism of treatment failure. Poor metabolizers, who are able to maintain a higher intra-gastric $\mathrm{pH}$ on PPI therapy, have a better response to dual therapy regardless of PPI dose, but genotype is less of a factor as PPI doses are increased [107]. Amoxicillin dosing frequency is an important factor as well. Amoxicillin, unlike many other antibiotics used in $H$. pylori treatment regimens, is time-dependent, not concentrationdependent, so time above MIC is an important factor in efficacy [108, 109]. A regimen of four times daily rabeprazole (20mg) and four times daily amoxicillin (750mg) for 14 days was recently shown to be superior to standard treatment regimens in a Taiwanese population [110]. Optimization of acid suppression may ultimately lead to a standard dual therapy regimen that is effective worldwide.

High dose PPI use in dual or standard therapy regimens may ultimately be replaced by more potent acid suppressive agents. The potassium competitive inhibitor of the gastric $\mathrm{H}, \mathrm{K}$ ATPase, vonoprazan, is coming into clinical use in Asia and has the benefit of a more rapid and sustained acid inhibitory effect regardless of CYP 2C19 genotype [111]. Use of vonoprazan in place of PPI has shown early promise in recent studies of Japanese populations, with an eradication rate of $70.2 \%$ using vonoprazan, amoxicillin, and clarithromycin as second line therapy in patients who have failed first line treatment with rabeprazole, amoxicillin, and clarithromycin and a $92.7 \%$ success rate of first line therapy with vonoprazan, amoxicillin, and clarithromycin [112, 113].

Non-antibiotic regimens would be the ideal for future management of $H$. pylori infection as this would avoid the concerning issue of worsening widespread antibiotic resistance. Potential treatments would target the components of acid acclimation that allow the bacteria to colonize the stomach, such as the urea channel, the two-component signaling systems that detect medium $\mathrm{pH}$, or the carbonic anhydrase enzymes. Inhibition or gene knockout of acarbonic anhydrase has shown promise in vitro as a potential treatment target in the presence of acid [30]. Acetazolamide, a carbonic anhydrase inhibitor used clinically for altitude sickness or alkalosis, were shown to have benefit for ulcer healing prior to the discovery of H. pylori [114]. One pilot study done in humans, looking at efficacy of acetazolamide in eradication of $H$. pylori, was unsuccessful, but the dose and duration of treatment were likely inappropriate $[115,116]$. Use of non-antibiotic targeted treatments of this nature would require attention to obstacles not only of dose and duration, but also to targeted treatment to bacteria in the gastric lumen. 


\section{Conclusions}

H. pylori is a highly prevalent global pathogen that causes chronic inflammation in all who are infected, carries a risk of advanced disease including ulcers and gastric cancer, and faces growing challenges with treatment efficacy. Standard triple therapy with proton pump inhibitor, clarithromycin, and either amoxicillin or metronidazole is no longer sufficiently efficacious in many parts of the world due to antibiotic resistance patterns. New regimens with bismuth, different antibiotics, or different combinations of standard antibiotics have shown variable promise. As antibiotic use for a variety of different infections increases, the problems inherent with the use of primarily antibiotic-based regimens for H. pylori will only increase. Use of enhanced acid suppression to improve efficacy of growth-dependent antibiotics, preference for regimens including antibiotics with lower risk for resistance, and continued focus on the search for non-antibiotic treatment targets will shape the future of treatment for $H$. pylori. Choice of regimens for patients in the present time should be based on knowledge of local resistance patterns and antibiotic use, patient history, and accommodations to facilitate optimal compliance.

\section{Acknowledgements}

The authors are supported by K08DK100661 (EAM), UCLA CDI (EAM), USVA 2I01BX001006 (GS), R01DK105156-01(GS).

\section{References}

1. Marshall BJ, Warren JR. Unidentified curved bacilli in the stomach of patients with gastritis and peptic ulceration. Lancet. 1984; 1(8390):1311-5. [PubMed: 6145023]

2. Blaser MJ. Hypotheses on the pathogenesis and natural history of Helicobacter pylori-induced inflammation. Gastroenterology. 1992; 102(2):720-7. [PubMed: 1732141]

3. Nomura A, Stemmermann GN, Chyou PH, Kato I, Perez-Perez GI, Blaser MJ. Helicobacter pylori infection and gastric carcinoma among Japanese Americans in Hawaii. The New England journal of medicine. 1991; 325(16):1132-6. [PubMed: 1891021]

4. Parsonnet J. Gastric adenocarcinoma and Helicobacter pylori infection. The Western journal of medicine. 1994; 161(1):60. [PubMed: 7941511]

5. Parsonnet J, Friedman GD, Vandersteen DP, Chang Y, Vogelman JH, Orentreich N, et al. Helicobacter pylori infection and the risk of gastric carcinoma. The New England journal of medicine. 1991; 325(16):1127-31. [PubMed: 1891020]

6. Suerbaum S, Michetti P. Helicobacter pylori infection. The New England journal of medicine. 2002; 347(15):1175-86. [PubMed: 12374879]

7. Cancer, IAfRo, editor. IARC monographs on the evaluation of the carcinogenic risk to humansSchistosomes, liver flukes, and Helicobacter pylori. Lyon, France: 1994. Infection with Helicobacter pylori; p. 177-240.

8. Bosman, FT.; Carneiro, F.; Hruban, RH.; Theise, ND. WHO: Classification of tumors of the digestive system. 4th. IARC Press; Geneva: 2010.

9. Ferlay J, Shin HR, Bray F, Forman D, Mathers C, Parkin DM. Estimates of worldwide burden of cancer in 2008: GLOBOCAN 2008. International journal of cancer. 2008; 127(12):2893-917. [PubMed: 21351269]

10. Ford AC, Delaney BC, Forman D, Moayyedi P. Eradication therapy for peptic ulcer disease in Helicobacter pylori positive patients. Cochrane database of systematic reviews (Online). 2006; (2):CD003840.

11. Gisbert JP, Khorrami S, Carballo F, Calvet X, Gene E, Dominguez-Munoz JE. H. pylori eradication therapy vs. antisecretory non-eradication therapy (with or without long-term maintenance 
antisecretory therapy) for the prevention of recurrent bleeding from peptic ulcer. Cochrane database of systematic reviews (Online). 2003; (4):CD004062.

12. Leodolter A, Kulig M, Brasch H, Meyer-Sabellek W, Willich SN, Malfertheiner P. A meta-analysis comparing eradication, healing and relapse rates in patients with Helicobacter pylori-associated gastric or duodenal ulcer. Alimentary pharmacology \& therapeutics. 2001; 15(12):1949-58. [PubMed: 11736726]

13. Chen LT, Lin JT, Tai JJ, Chen GH, Yeh HZ, Yang SS, et al. Long-term results of anti-Helicobacter pylori therapy in early-stage gastric high-grade transformed MALT lymphoma. Journal of the National Cancer Institute. 2005; 97(18):1345-53. [PubMed: 16174856]

14. Stathis A, Chini C, Bertoni F, Proserpio I, Capella C, Mazzucchelli L, et al. Long-term outcome following Helicobacter pylori eradication in a retrospective study of 105 patients with localized gastric marginal zone B-cell lymphoma of MALT type. Ann Oncol. 2009; 20(6):1086-93. [PubMed: 19193705]

15. Wotherspoon AC, Doglioni C, Diss TC, Pan L, Moschini A, de Boni M, et al. Regression of primary low-grade B-cell gastric lymphoma of mucosa-associated lymphoid tissue type after eradication of Helicobacter pylori. Lancet. 1993; 342(8871):575-7. [PubMed: 8102719]

16. Wong BC, Lam SK, Wong WM, Chen JS, Zheng TT, Feng RE, et al. Helicobacter pylori eradication to prevent gastric cancer in a high-risk region of China: a randomized controlled trial. Jama. 2004; 291(2):187-94. [PubMed: 14722144]

17. Tulassay Z, Stolte M, Engstrand L, Butruk E, Malfertheiner P, Dite P, et al. Twelve-month endoscopic and histological analysis following proton-pump inhibitor-based triple therapy in Helicobacter pylori-positive patients with gastric ulcers. Scandinavian journal of gastroenterology. 2010; 45(9):1048-58. [PubMed: 20509752]

18. Graham DY, Lu H, Yamaoka Y. A report card to grade Helicobacter pylori therapy. Helicobacter. 2007; 12(4):275-8. doi:10.1111/j.1523-5378.2007.00518.x. [PubMed: 17669098]

19. Kim SY, Choi DJ, Chung JW. Antibiotic treatment for Helicobacter pylori: Is the end coming? World J Gastrointest Pharmacol Ther. 2015; 6(4):183-98. doi:10.4292/wjgpt.v6.i4.183. *Provides a helpful overview of worldwide antibiotic resistance patterns. [PubMed: 26558152]

20. Teyssen S, Chari ST, Scheid J, Singer MV. Effect of repeated boluses of intravenous omeprazole and primed infusions of ranitidine on 24-hour intragastric $\mathrm{pH}$ in healthy human subjects. Digestive diseases and sciences. 1995; 40(2):247-55. [PubMed: 7851185]

21. Code CF. Defense mechanisms of the gastric mucosa. Scand J Gastroenterol Suppl. 1981; 67:2014. [PubMed: 7017894]

22. Henriksnas J, Phillipson M, Storm M, Engstrand L, Soleimani M, Holm L. Impaired mucusbicarbonate barrier in Helicobacter pylori-infected mice. American journal of physiology. 2006; 291(3):G396-403. [PubMed: 16614375]

23. Baumgartner HK, Montrose MH. Regulated alkali secretion acts in tandem with unstirred layers to regulate mouse gastric surface pH. Gastroenterology. 2004; 126(3):774-83. [PubMed: 14988832]

24. Scott DR, Marcus EA, Wen Y, Oh J, Sachs G. Gene expression in vivo shows that Helicobacter pylori colonizes an acidic niche on the gastric surface. Proceedings of the National Academy of Sciences of the United States of America. 2007; 104(17):7235-40. [PubMed: 17438279]

25. Larkin CJ, Watson RGP, Sloan JM, Stevenson M, Ardill JE, Buchanan D. Distribution of atrophy in Helicobacter pylori-infected subjects taking proton pump inhibitors. Scandinavian journal of gastroenterology. 2000; 35(6):578-82. [PubMed: 10912656]

26. Lee A, Dixon MF, Danon SJ, Kuipers E, Megraud F, Larsson H, et al. Local acid production and Helicobacter pylori: a unifying hypothesis of gastroduodenal disease. Eur J Gastroenterol Hepatol. 1995; 7(5):461-5. [PubMed: 7614109]

27. Logan RP, Walker MM, Misiewicz JJ, Gummett PA, Karim QN, Baron JH. Changes in the intragastric distribution of Helicobacter pylori during treatment with omeprazole. Gut. 1995; 36(1):12-6. [PubMed: 7890214]

28. Mollenhauer-Rektorschek M, Hanauer G, Sachs G, Melchers K. Expression of UreI is required for intragastric transit and colonization of gerbil gastric mucosa by Helicobacter pylori. Research in microbiology. 2002; 153(10):659-66. [PubMed: 12558185] 
29. Meyer-Rosberg K, Scott DR, Rex D, Melchers K, Sachs G. The effect of environmental pH on the proton motive force of Helicobacter pylori. Gastroenterology. 1996; 111(4):886-900. [PubMed: 8831583]

30. Marcus EA, Moshfegh AP, Sachs G, Scott DR. The periplasmic alpha-carbonic anhydrase activity of Helicobacter pylori is essential for acid acclimation. Journal of bacteriology. 2005; 187(2):72938. [PubMed: 15629943]

31. Ma Z, Gong S, Richard H, Tucker DL, Conway T, Foster JW. GadE (YhiE) activates glutamate decarboxylase-dependent acid resistance in Escherichia coli K-12. Molecular microbiology. 2003; 49(5):1309-20. [PubMed: 12940989]

32. Scott DR, Marcus EA, Weeks DL, Lee A, Melchers K, Sachs G. Expression of the Helicobacter pylori ureI gene is required for acidic $\mathrm{pH}$ activation of cytoplasmic urease. Infection and immunity. 2000; 68(2):470-7. [PubMed: 10639406]

33. Weeks DL, Eskandari S, Scott DR, Sachs G. A H+-gated urea channel: the link between Helicobacter pylori urease and gastric colonization. Science (New York, NY. 2000; 287(5452): 482-5.

34. Marcus EA, Sachs G, Wen Y, Feng J, Scott DR. Role of the Helicobacter pylori sensor kinase ArsS in protein trafficking and acid acclimation. Journal of bacteriology. 2012; 194(20):5545-51. [PubMed: 22865848]

35. Marcus EA, Inatomi N, Nagami GT, Sachs G, Scott DR. The effects of varying acidity on Helicobacter pylori growth and the bactericidal efficacy of ampicillin. Alimentary pharmacology \& therapeutics. 2012; 36(10):972-9. [PubMed: 23009227]

36. Graham DY, Fischbach L. Helicobacter pylori treatment in the era of increasing antibiotic resistance. Gut. 2010; 59(8):1143-53. [PubMed: 20525969]

37. Molina-Infante J, Shiotani A. Practical Aspects in Choosing a Helicobacter pylori Therapy. Gastroenterology clinics of North America. 2015; 44(3):519-35. doi:10.1016/j.gtc.2015.05.004. **A clearly written and rational guide explaining why different treatment regimens may be appropriate or less ideal for $H$. pylori infection in specific circumstances. [PubMed: 26314666]

38. Sugimoto M, Shirai N, Nishino M, Kodaira C, Uotani T, Yamade M, et al. Rabeprazole $10 \mathrm{mg}$ q.d.s. decreases 24 -h intragastric acidity significantly more than rabeprazole $20 \mathrm{mg}$ b.d. or $40 \mathrm{mg}$ o.m., overcoming CYP2C19 genotype. Alimentary pharmacology \& therapeutics. 2012; 36(7): 627-34. doi:10.1111/apt.12014. [PubMed: 22882464]

39. Gisbert JP, Gonzalez L, Calvet X, Garcia N, Lopez T, Roque M, et al. Proton pump inhibitor, clarithromycin and either amoxycillin or nitroimidazole: a meta-analysis of eradication of Helicobacter pylori. Alimentary pharmacology \& therapeutics. 2000; 14(10):1319-28. [PubMed: 11012477]

40. Villoria A. [Acid-related diseases: are higher doses of proton pump inhibitors more effective in the treatment of Helicobacter pylori infection?]. Gastroenterol Hepatol. 2008; 31(8):546-7. [PubMed: 18928760]

41. Calvet X, Garcia N, Lopez T, Gisbert JP, Gene E, Roque M. A meta-analysis of short versus long therapy with a proton pump inhibitor, clarithromycin and either metronidazole or amoxycillin for treating Helicobacter pylori infection. Alimentary pharmacology \& therapeutics. 2000; 14(5):6039. [PubMed: 10792124]

42. Ford A, Moayyedi P. How can the current strategies for Helicobacter pylori eradication therapy be improved? Can J Gastroenterol. 2003; 17(Suppl B):36B-40B.

43. Fuccio L, Minardi ME, Zagari RM, Grilli D, Magrini N, Bazzoli F. Meta-analysis: duration of firstline proton-pump inhibitor based triple therapy for Helicobacter pylori eradication. Annals of internal medicine. 2007; 147(8):553-62. [PubMed: 17938394]

44. Lind T, Veldhuyzen van Zanten S, Unge P, Spiller R, Bayerdorffer E, O'Morain C, et al. Eradication of Helicobacter pylori using one-week triple therapies combining omeprazole with two antimicrobials: the MACH I Study. Helicobacter. 1996; 1(3):138-44. [PubMed: 9398894]

45. Malfertheiner P, Megraud F, O'Morain C, Bell D, Bianchi Porro G, Deltenre M, et al. Current European concepts in the management of Helicobacter pylori infection--the Maastricht Consensus Report. The European Helicobacter Pylori Study Group (EHPSG). Eur J Gastroenterol Hepatol. 1997; 9(1):1-2. [PubMed: 9031888] 
46. Khalifa MM, Sharaf RR, Aziz RK. Helicobacter pylori: a poor man's gut pathogen? Gut Pathog. 2010; 2(1):2. doi:10.1186/1757-4749-2-2. [PubMed: 20356368]

47. Malfertheiner P, Megraud F, O'Morain CA, Atherton J, Axon AT, Bazzoli F, et al. Management of Helicobacter pylori infection--the Maastricht IV/ Florence Consensus Report. Gut. 2012; 61(5): 646-64. [PubMed: 22491499]

48. Megraud F. H pylori antibiotic resistance: prevalence, importance, and advances in testing. Gut. 2004; 53(9):1374-84. [PubMed: 15306603]

49. Webber MA, Piddock LJ. The importance of efflux pumps in bacterial antibiotic resistance. J Antimicrob Chemother. 2003; 51(1):9-11. [PubMed: 12493781]

50. McMahon BJ, Hennessy TW, Bensler JM, Bruden DL, Parkinson AJ, Morris JM, et al. The relationship among previous antimicrobial use, antimicrobial resistance, and treatment outcomes for Helicobacter pylori infections. Annals of internal medicine. 2003; 139(6):463-9. [PubMed: 13679322]

51. Goodwin A, Kersulyte D, Sisson G, Veldhuyzen van Zanten SJ, Berg DE, Hoffman PS. Metronidazole resistance in Helicobacter pylori is due to null mutations in a gene $(r d x A)$ that encodes an oxygen-insensitive NADPH nitroreductase. Molecular microbiology. 1998; 28(2):38393. [PubMed: 9622362]

52. Jenks PJ, Edwards DI. Metronidazole resistance in Helicobacter pylori. Int J Antimicrob Agents. 2002; 19(1):1-7. [PubMed: 11814762]

53. Chey WD, Wong BC, Practice Parameters Committee of the American College of G. American College of Gastroenterology guideline on the management of Helicobacter pylori infection. The American journal of gastroenterology. 2007; 102(8):1808-25. doi:10.1111/j. 1572-0241.2007.01393.x. [PubMed: 17608775]

54. Megraud F, Lamouliatte H. Review article: the treatment of refractory Helicobacter pylori infection. Alimentary pharmacology \& therapeutics. 2003; 17(11):1333-43. [PubMed: 12786627]

55. Zhang W, Chen Q, Liang X, Liu W, Xiao S, Graham DY, et al. Bismuth, lansoprazole, amoxicillin and metronidazole or clarithromycin as first-line Helicobacter pylori therapy. Gut. 2015; 64(11): 1715-20. doi:10.1136/gutjnl-2015-309900. [PubMed: 26338726]

56. Qureshi NN, Gallaher B, Schiller NL. Evolution of amoxicillin resistance of Helicobacter pylori in vitro: characterization of resistance mechanisms. Microb Drug Resist. 2014; 20(6):509-16. doi: 10.1089/mdr.2014.0019. [PubMed: 24901497]

57. Fischbach L, Evans EL. Meta-analysis: the effect of antibiotic resistance status on the efficacy of triple and quadruple first-line therapies for Helicobacter pylori. Alimentary pharmacology \& therapeutics. 2007; 26(3):343-57. doi:10.1111/j.1365-2036.2007.03386.x. [PubMed: 17635369]

58. Cao Z, Chen Q, Zhang W, Liang X, Liao J, Liu W, et al. Fourteen-day optimized levofloxacinbased therapy versus classical quadruple therapy for Helicobacter pylori treatment failures: a randomized clinical trial. Scandinavian journal of gastroenterology. 2015; 50(10):1185-90. doi: 10.3109/00365521.2015.1037345. [PubMed: 25881966]

59. Gisbert JP, Romano M, Gravina AG, Solis-Munoz P, Bermejo F, Molina-Infante J, et al. Helicobacter pylori second-line rescue therapy with levofloxacin- and bismuth-containing quadruple therapy, after failure of standard triple or non-bismuth quadruple treatments. Alimentary pharmacology \& therapeutics. 2015; 41(8):768-75. doi:10.1111/apt.13128. [PubMed: 25703120]

60. Liao J, Zheng Q, Liang X, Zhang W, Sun Q, Liu W, et al. Effect of fluoroquinolone resistance on 14-day levofloxacin triple and triple plus bismuth quadruple therapy. Helicobacter. 2013; 18(5): 373-7. doi:10.1111/hel.12052. [PubMed: 23581720]

61. Sun Q, Liang X, Zheng Q, Liu W, Xiao S, Gu W, et al. High efficacy of 14-day triple therapybased, bismuth-containing quadruple therapy for initial Helicobacter pylori eradication. Helicobacter. 2010; 15(3):233-8. doi:10.1111/j.1523-5378.2010.00758.x. [PubMed: 20557366]

62. Ge R, Chen Z, Zhou Q. The actions of bismuth in the treatment of Helicobacter pylori infections: an update. Metallomics. 2012; 4(3):239-43. doi:10.1039/c2mt00180b. [PubMed: 22358069]

63. Lambert JR, Midolo P. The actions of bismuth in the treatment of Helicobacter pylori infection. Alimentary pharmacology \& therapeutics. 1997; 11(Suppl 1):27-33. [PubMed: 9146788]

64. Thomas F, Bialek B, Hensel R. Medical use of bismuth: The two sides of the coin. Clinical Toxicology. 2012; S3 004:1-5. doi:10.4172/2161-0495. 
65. Lambert JR, Borromeo J, Eaves ER, Hansky J, Korman MG. Efficacy of different dosage regimens of bismuth in eradicating Campylobacter pylori. Gastroenterology. 1988; 94:A248.

66. Marshall BJ, Valenzuela JE, McCallum RW, Dooley CP, Guerrant RL, Cohen H, et al. Bismuth subsalicylate suppression of Helicobacter pylori in nonulcer dyspepsia: a double-blind placebocontrolled trial. Digestive diseases and sciences. 1993; 38(9):1674-80. [PubMed: 8359080]

67. McNulty CA. Bismuth subsalicylate in the treatment of gastritis due to Campylobacter pylori. Rev Infect Dis. 1990; 12(Suppl 1):S94-8. [PubMed: 2406863]

68. Phillips RH, Whitehead MW, Lacey S, Champion M, Thompson RP, Powell JJ. Solubility, absorption, and anti-Helicobacter pylori activity of bismuth subnitrate and colloidal bismuth subcitrate: In vitro data Do not predict In vivo efficacy. Helicobacter. 2000; 5(3):176-82. [PubMed: 10971684]

69. Armstrong JA, Wee SH, Goodwin CS, Wilson DH. Response of Campylobacter pyloridis to antibiotics, bismuth and an acid-reducing agent in vitro--an ultrastructural study. Journal of medical microbiology. 1987; 24(4):343-50. doi:10.1099/00222615-24-4-343. [PubMed: 3694664]

70. Marshall BJ, Armstrong JA, Francis GJ, Nokes NT, Wee SH. Antibacterial action of bismuth in relation to Campylobacter pyloridis colonization and gastritis. Digestion. 1987; 37(Suppl 2):1630. [PubMed: 3622946]

71. Marcus EA, Sachs G, Scott DR. Colloidal bismuth subcitrate impedes proton entry into Helicobacter pylori and increases the efficacy of growth-dependent antibiotics. Alimentary pharmacology \& therapeutics. 2015 doi:10.1111/apt.13346.

72. Just PM. Overview of the fluoroquinolone antibiotics. Pharmacotherapy. 1993; 13(2):4S-17S. Pt 2. [PubMed: 8386356]

73. Cattoir V, Nectoux J, Lascols C, Deforges L, Delchier JC, Megraud F, et al. Update on fluoroquinolone resistance in Helicobacter pylori: new mutations leading to resistance and first description of a gyrA polymorphism associated with hypersusceptibility. Int J Antimicrob Agents. 2007; 29(4):389-96. doi:10.1016/j.ijantimicag.2006.11.007. [PubMed: 17303392]

74. Moore RA, Beckthold B, Wong S, Kureishi A, Bryan LE. Nucleotide sequence of the gyrA gene and characterization of ciprofloxacin-resistant mutants of Helicobacter pylori. Antimicrobial agents and chemotherapy. 1995; 39(1):107-11. [PubMed: 7695290]

75. Chuah SK, Tai WC, Hsu PI, Wu DC, Wu KL, Kuo CM, et al. The efficacy of second-line antiHelicobacter pylori therapy using an extended 14-day levofloxacin/amoxicillin/proton-pump inhibitor treatment--a pilot study. Helicobacter. 2012; 17(5):374-81. doi:10.1111/j. 1523-5378.2012.00960.x. [PubMed: 22967121]

76. Thung I, Aramin H, Vavinskaya V, Gupta S, Park JY, Crowe SE, et al. Review article: the global emergence of Helicobacter pylori antibiotic resistance. Alimentary pharmacology \& therapeutics. 2016; 43(4):514-33. doi:10.1111/apt.13497. **Provides a comprehensive overview of antibiotic resistance mechanisms, how to test for antibiotic resistance, and how to target therapy based on these results. [PubMed: 26694080]

77. Gerrits MM, de Zoete MR, Arents NL, Kuipers EJ, Kusters JG. 16S rRNA mutation-mediated tetracycline resistance in Helicobacter pylori. Antimicrobial agents and chemotherapy. 2002; 46(9):2996-3000. [PubMed: 12183259]

78. Chi CH, Lin CY, Sheu BS, Yang HB, Huang AH, Wu JJ. Quadruple therapy containing amoxicillin and tetracycline is an effective regimen to rescue failed triple therapy by overcoming the antimicrobial resistance of Helicobacter pylori. Alimentary pharmacology \& therapeutics. 2003; 18(3):347-53. [PubMed: 12895220]

79. Delchier JC, Malfertheiner P, Thieroff-Ekerdt R. Use of a combination formulation of bismuth, metronidazole and tetracycline with omeprazole as a rescue therapy for eradication of Helicobacter pylori. Alimentary pharmacology \& therapeutics. 2014; 40(2):171-7. doi:10.1111/apt.12808. [PubMed: 24863854]

80. Laine L, Hunt R, El-Zimaity H, Nguyen B, Osato M, Spenard J. Bismuth-based quadruple therapy using a single capsule of bismuth biskalcitrate, metronidazole, and tetracycline given with omeprazole versus omeprazole, amoxicillin, and clarithromycin for eradication of Helicobacter pylori in duodenal ulcer patients: a prospective, randomized, multicenter, North American trial. The American journal of gastroenterology. 2003; 98(3):562-7. [PubMed: 12650788] 
81. Malfertheiner P, Bazzoli F, Delchier JC, Celinski K, Giguere M, Riviere M, et al. Helicobacter pylori eradication with a capsule containing bismuth subcitrate potassium, metronidazole, and tetracycline given with omeprazole versus clarithromycin-based triple therapy: a randomised, open-label, non-inferiority, phase 3 trial. Lancet. 2011; 377(9769):905-13. doi:10.1016/ S0140-6736(11)60020-2. [PubMed: 21345487]

82. O'Morain C, Borody T, Farley A, De Boer WA, Dallaire C, Schuman R, et al. Efficacy and safety of single-triple capsules of bismuth biskalcitrate, metronidazole and tetracycline, given with omeprazole, for the eradication of Helicobacter pylori: an international multicentre study. Alimentary pharmacology \& therapeutics. 2003; 17(3):415-20. [PubMed: 12562455]

83. Muller N, Amiot A, Le Thuaut A, Bastuji-Garin S, Deforges L, Delchier JC. Rescue therapy with bismuth-containing quadruple therapy in patients infected with metronidazole-resistant Helicobacter pylori strains. Clin Res Hepatol Gastroenterol. 2016 doi:10.1016/j.clinre. 2015.12.012.

84. Heep M, Beck D, Bayerdorffer E, Lehn N. Rifampin and rifabutin resistance mechanism in Helicobacter pylori. Antimicrobial agents and chemotherapy. 1999; 43(6):1497-9. [PubMed: 10348780]

85. Heep M, Rieger U, Beck D, Lehn N. Mutations in the beginning of the rpoB gene can induce resistance to rifamycins in both Helicobacter pylori and Mycobacterium tuberculosis. Antimicrobial agents and chemotherapy. 2000; 44(4):1075-7. [PubMed: 10722516]

86. Borody TJ, Pang G, Wettstein AR, Clancy R, Herdman K, Surace R, et al. Efficacy and safety of rifabutin-containing 'rescue therapy' for resistant Helicobacter pylori infection. Alimentary pharmacology \& therapeutics. 2006; 23(4):481-8. doi:10.1111/j.1365-2036.2006.02793.x. [PubMed: 16441468]

87. Lim HC, Lee YJ, An B, Lee SW, Lee YC, Moon BS. Rifabutin-based high-dose proton-pump inhibitor and amoxicillin triple regimen as the rescue treatment for Helicobacter pylori. Helicobacter. 2014; 19(6):455-61. doi:10.1111/hel.12147. [PubMed: 25231089]

88. Gisbert JP, Calvet X. Review article: rifabutin in the treatment of refractory Helicobacter pylori infection. Alimentary pharmacology \& therapeutics. 2012; 35(2):209-21. doi:10.1111/j. 1365-2036.2011.04937.x. [PubMed: 22129228]

89. Romano M, Cuomo A, Gravina AG, Miranda A, Iovene MR, Tiso A, et al. Empirical levofloxacincontaining versus clarithromycin-containing sequential therapy for Helicobacter pylori eradication: a randomised trial. Gut. 2010; 59(11):1465-70. doi:10.1136/gut.2010.215350. [PubMed: 20947881]

90. Zullo A, Hassan C, Morini S, De Francesco V, Ierardi E, Panella C, et al. Sequential therapy for $H$. pylori: an 'aberrant' therapy ready for general use. Dig Liver Dis. 2004; 36(12):852-3. author reply 3. [PubMed: 15646435]

91. Liou JM, Chen CC, Chen MJ, Chen CC, Chang CY, Fang YJ, et al. Sequential versus triple therapy for the first-line treatment of Helicobacter pylori: a multicentre, open-label, randomised trial. Lancet. 2013; 381(9862):205-13. doi:10.1016/S0140-6736(12)61579-7. [PubMed: 23158886]

92. Gisbert JP, Calvet X, O'Connor A, Megraud F, O'Morain CA. Sequential therapy for Helicobacter pylori eradication: a critical review. J Clin Gastroenterol. 2010; 44(5):313-25. doi:10.1097/MCG. 0b013e3181c8a1a3. [PubMed: 20054285]

93. Liou JM, Chen CC, Lee YC, Chang CY, Wu JY, Bair MJ, et al. Systematic review with metaanalysis: 10- or 14-day sequential therapy vs. 14-day triple therapy in the first line treatment of Helicobacter pylori infection. Alimentary pharmacology \& therapeutics. 2016; 43(4):470-81. doi: 10.1111/apt.13495. [PubMed: 26669729]

94. Graham DY, Shiotani A. Which Therapy for Helicobacter pylori Infection? Gastroenterology. 2012; 143(1):10-2. doi:10.1053/j.gastro.2012.05.012. [PubMed: 22613622]

95. Essa AS, Kramer JR, Graham DY, Treiber G. Meta-analysis: four-drug, three-antibiotic, nonbismuth-containing "concomitant therapy" versus triple therapy for Helicobacter pylori eradication. Helicobacter. 2009; 14(2):109-18. doi:10.1111/j.1523-5378.2009.00671.x. [PubMed: 19298338]

96. Georgopoulos S, Papastergiou V, Xirouchakis E, Laoudi F, Lisgos P, Spiliadi C, et al. Nonbismuth quadruple "concomitant" therapy versus standard triple therapy, both of the duration of 10 days, 
for first-line H. pylori eradication: a randomized trial. J Clin Gastroenterol. 2013; 47(3):228-32. doi:10.1097/MCG.0b013e31826015b0. [PubMed: 22858517]

97. Gisbert JP, Calvet X. Update on non-bismuth quadruple (concomitant) therapy for eradication of Helicobacter pylori. Clin Exp Gastroenterol. 2012; 5:23-34. doi:10.2147/CEG.S25419. [PubMed: 22457599]

98. Graham DY, Lee YC, Wu MS. Rational Helicobacter pylori therapy: evidence-based medicine rather than medicine-based evidence. Clin Gastroenterol Hepatol. 2014; 12(2):177-86. e3; Discussion e12-3. doi:10.1016/j.cgh.2013.05.028. [PubMed: 23751282]

99. Hsu PI, Wu DC, Wu JY, Graham DY. Modified sequential Helicobacter pylori therapy: proton pump inhibitor and amoxicillin for 14 days with clarithromycin and metronidazole added as a quadruple (hybrid) therapy for the final 7 days. Helicobacter. 2011; 16(2):139-45. doi:10.1111/j. 1523-5378.2011.00828.x. [PubMed: 21435092]

100. Hsu PI, Lin PC, Graham DY. Hybrid therapy for Helicobacter pylori infection: A systemic review and meta-analysis. World J Gastroenterol. 2015; 21(45):12954-62. doi:10.3748/

wjg.v21.i45.12954. [PubMed: 26668516]

101. Wang B, Wang YH, Lv ZF, Xiong HF, Wang H, Yang Y, et al. Review: efficacy and safety of hybrid therapy for Helicobacter pylori infection: a systematic review and meta-analysis. Helicobacter. 2015; 20(2):79-88. doi:10.1111/hel.12180. [PubMed: 25381839]

102. Glupczynski Y, Megraud F, Lopez-Brea M, Andersen LP. European multicentre survey of in vitro antimicrobial resistance in Helicobacter pylori. Eur J Clin Microbiol Infect Dis. 2001; 20(11): 820-3. [PubMed: 11783701]

103. Heep M, Kist M, Strobel S, Beck D, Lehn N. Secondary resistance among 554 isolates of Helicobacter pylori after failure of therapy. Eur J Clin Microbiol Infect Dis. 2000; 19(7):538-41. [PubMed: 10968325]

104. Meyer JM, Silliman NP, Wang W, Siepman NY, Sugg JE, Morris D, et al. Risk factors for Helicobacter pylori resistance in the United States: the surveillance of $H$. pylori antimicrobial resistance partnership (SHARP) study, 1993-1999. Annals of internal medicine. 2002; 136(1): 13-24. [PubMed: 11777360]

105. Graham KS, Malaty H, el-Zimaity HM, Genta RM, Cole RA, al-Assi MT, et al. Variability with omeprazole-amoxicillin combinations for treatment of Helicobacter pylori infection. The American journal of gastroenterology. 1995; 90(9):1415-8. [PubMed: 7661160]

106. Sjostedt S, Sagar M, Lindberg G, Wikstrom B, Nord CE, Seensalu R. Prolonged and profound acid inhibition is crucial in Helicobacter pylori treatment with a proton pump inhibitor combined with amoxicillin. Scandinavian journal of gastroenterology. 1998; 33(1):39-43. [PubMed: 9489906]

107. Yang JC, Wang HL, Chern HD, Shun CT, Lin BR, Lin CJ, et al. Role of omeprazole dosage and cytochrome P450 2C19 genotype in patients receiving omeprazole-amoxicillin dual therapy for Helicobacter pylori eradication. Pharmacotherapy. 2011; 31(3):227-38. doi:10.1592/phco. 31.3.227. [PubMed: 21361732]

108. MacGowan AP, Bowker KE. Continuous infusion of beta-lactam antibiotics. Clin Pharmacokinet. 1998; 35(5):391-402. [PubMed: 9839090]

109. Midolo PD, Turnidge JD, Munckhof WJ. Is bactericidal activity of amoxicillin against Helicobacter pylori concentration dependent? Antimicrobial agents and chemotherapy. 1996; 40(5):1327-8. [PubMed: 8723498]

110. Yang JC, Lin CJ, Wang HL, Chen JD, Kao JY, Shun CT, et al. High-dose Dual Therapy Is Superior to Standard First-line or Rescue Therapy for Helicobacter pylori Infection. Clin Gastroenterol Hepatol. 2015; 13(5):895-905. e5. doi:10.1016/j.cgh.2014.10.036. *Offers promise for the future of therapy for $H$. pylori, with an option for decreased antibiotic use, although results are not currently generalizable worldwide. [PubMed: 25460556]

111. Sakurai Y, Mori Y, Okamoto H, Nishimura A, Komura E, Araki T, et al. Acid-inhibitory effects of vonoprazan $20 \mathrm{mg}$ compared with esomeprazole $20 \mathrm{mg}$ or rabeprazole $10 \mathrm{mg}$ in healthy adult male subjects-a randomised open-label cross-over study. Alimentary pharmacology \& therapeutics. 2015 doi:10.1111/apt.13325.

Curr Gastroenterol Rep. Author manuscript; available in PMC 2017 July 01. 
112. Inaba T, Iwamuro M, Toyokawa T, Okada H. Letter: promising results of Helicobacter pylori eradication with vonoprazan-based triple therapy after failure of proton pump inhibitor-based triple therapy. Alimentary pharmacology \& therapeutics. 2016; 43(1):179-80. doi:10.1111/apt. 13462. [PubMed: 26638943]

113. Murakami KSY, Shiino M, Funao N, Nishimura A, Asaka M. A phase 3, double-blind study of a triple therapy with TAK-438, amoxicillin, and clarithromycin as first line eradication of $H$. pylori and a triple therapy with TAK-438, amoxicillin, and metronidazole as second line eradication of H. pylori. Gastroenterology. 2014; 146(Suppl. 5):S-740.

114. Puscas I. Treatment of gastroduodenal ulcers with carbonic anhydrase inhibitors. Ann N Y Acad Sci. 1984; 429:587-91. [PubMed: 6378030]

115. Buzas GM. Carbonic anhydrase, acetazolamide and Helicobacter pylori infection. Helicobacter. 2005; 10(5):444. doi:10.1111/j.1523-5378.2005.00353.x. [PubMed: 16181356]

116. Shahidzadeh R, Opekun A, Shiotani A, Graham DY. Effect of the carbonic anhydrase inhibitor, acetazolamide, on Helicobacter pylori infection in vivo: a pilot study. Helicobacter. 2005; 10(2): 136-8. doi:10.1111/j.1523-5378.2005.00306.x. [PubMed: 15810944] 